\title{
Reactivation of antibiosis in the entomogenous fungus Chrysoporthe sp. SNB-CN74
}

\author{
Charlotte Nirma ${ }^{1,2}$, Véronique Eparvier ${ }^{1}$ and Didier Stien ${ }^{1,3}$
}

Chrysoporthe sp. SNB-CN74 was isolated from a Nasutitermes corniger nest, and its ethyl acetate extract was found to exhibit very strong antibacterial activity. Two antibacterial metabolites were isolated, (-)- $R$-skyrin (2) and (+)-rugulosin A (3). Eventually, the fungus lost its antibiotic potential when subcultured, and the use of yeast extract induced the re-expression of these two antibiotics. Yeast extract possibly activated a cryptic pathway by mimicking the presence of an ecological competitor.

The Journal of Antibiotics (2015) 68, 586-590; doi:10.1038/ja.2015.36; published online 15 April 2015

\section{INTRODUCTION}

It is urgent to find new antibiotic compounds because of increased pathogen resistance to the available antimicrobials. It is with this objective that we became interested in exploring new resources of natural substances, and in particular, social insect symbiotic microorganisms. According to the literature data and because insects, fungi and bacteria represent the most diverse and unknown groups of living organisms, ${ }^{1}$ they should be considered as an innovative, ecologically relevant source of antimicrobial compounds. ${ }^{2-13}$ Indeed, eusociality should in principle favor the transmission of infectious pathogens (many individuals, promiscuity, frequent interactions and genetic homogeneity), and it has been observed that social insects have developed mutually beneficial associations with microorganisms that provide antimicrobial agents to the colonies, improving the fitness of the host insect. Several antimicrobial compounds have been isolated from insect symbiotic microorganisms. ${ }^{2,14}$ However, few studies have been conducted on termite symbionts. ${ }^{15-17}$ We have thus embarked into characterizing antimicrobial agents from Guianese termite symbionts in the search for compounds that may eventually be useful in human health. ${ }^{17,18}$ An ethyl acetate extract of a fungus isolated from a Nasutitermes corniger nest, identified as Chrysoporthe sp. SNB-CN74, was strongly antibacterial ( $\mathrm{MIC}=16 \mu \mathrm{g} \mathrm{ml}^{-1}$ on Staphylococcus aureus and Escherichia coli). However, the fungus lost its antibacterial potential when it was subcultured. The present article describes our efforts to recover the antibacterial activity of the fungus and to identify the compounds responsible for this activity.

\section{RESULTS AND DISCUSSION}

\section{Characterization of antibacterial metabolites}

Initially, the only active extract obtained was the extract used for the screening. With $75.7 \mathrm{mg}$, we undertook to isolate the active metabolites by bioactivity-guided fractionation. Three compounds were isolated and characterized, and the antibacterial potential was supported by compounds $\mathbf{2}$ and $\mathbf{3}$ (Figure 1). Compound $\mathbf{1}$ was new to science. These metabolites have been identified by high-resolution MS, NMR and spectroscopic analyses.

Compound 1 was a colorless oil. The molecular formula $\mathrm{C}_{15} \mathrm{H}_{22} \mathrm{O}_{3}$ was determined via high-resolution ESI time-of-flight mass MS analysis, which showed a pseudomolecular ion peak at $\mathrm{m} / z 251.1650$ $[\mathrm{M}+\mathrm{H}]^{+}$(calculated (calcd) for $\mathrm{C}_{15} \mathrm{H}_{23} \mathrm{O}_{3}, 251.1647$ ). This formula implied five degrees of unsaturation. The NMR spectrum in $\mathrm{CDCl}_{3}$ suggested the presence of three olefinic protons at $\delta 5.21,5.29$ and 5.35 and four protons on oxygenated carbons at $\delta 3.19,4.19,4.32$ and 4.53. Protons at $\delta 5.29$ and 5.35 , as well as those at $\delta 4.19$ and 4.32 were linked to the same carbons ( $\delta 115.4$ and 64.0, respectively; Table 1). Two methyl groups were also present. The first one was a doublet at $\delta 1.01$ and the second one was a singlet at $\delta 1.03$. It was possible to describe a cyclohexane A-ring following the sequence of the COSY correlations along the left side of the molecule (1-15), and it was eventually found that compound 1 was an octahydronaphtalene based on the COSY and HMBC correlations between the two parts of the molecule (Figure 2). In particular, H-lax correlated with $\mathrm{H}-8$ and $\mathrm{H}-9$, whereas in the HMBC, H-6 and the bridgehead methyl group $\mathrm{H}-14$ both correlated with the central quaternary carbons C-5 and C-10. Finally, an isopropenyl substituent was elucidated within positions 12, 11 and 13, and this substituent was linked to carbon 7 based on the HMBC experiment.

Because the molecule contained three oxygens and had four carbons linked to oxygens, it remained to ascertain the position of one heterocycle to reach the right crude formulae. The H-6 chemical shift at $\delta 3.19$ was rather upfield, a fact that suggested the presence of an epoxide between C-6 and C-7. The NMR spectrum was recorded in

${ }^{1}$ Department of Natural Products and Medicinal Chemistry, CNRS - Institut de Chimie des Substances Naturelles, Gif-sur-Yvette, France; ${ }^{2}$ CNRS, UMR ECOFOG, Institut Pasteur de la Guyane, Cayenne, France and ${ }^{3}$ Sorbonne Universités, UPMC Univ Paris 06, CNRS, Laboratoire de Biodiversité et Biotechnologies Microbiennes (LBBM), Observatoire Océanologique, Banyuls-sur-mer, France

Correspondence: Dr C Nirma or V Eparvier, Department of Natural Products and Medicinal Chemistry, CNRS - Institut de Chimie des Substances Naturelles, 1 Avenue de la Terrasse, 91198 Gif-sur-Yvette, France.

E-mail: charlotte.nirma@live.fr

Received 21 January 2015; revised 6 March 2015; accepted 16 March 2015; published online 15 April 2015 
dimethyl sulfoxide $d 6$ (DMSO-d6) to observe labile protons and their couplings with $\mathrm{CH}$ (Supplementary Table S1 in the Supplementary Information). Additional coupling was observed in $\mathrm{H}-8$ and $\mathrm{H}-13$, whereas $\mathrm{H}-6$ remained singlet, thus confirming the presumed position of the additional unsaturation in the form of an oxiran ring. The analytical data are consistent with those described in the literature for epoxydecalins such as phomenone and the phomodecalins. ${ }^{19-21}$ Compound 1 has not been previously described in the literature and was given the trivial name phomenol after the structurally related phomenone.

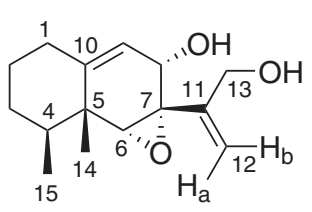<smiles>Cc1cc(O)c2c(c1)C(=O)c1c(c(O)cc(O)c1-c1c(O)cc(O)c3c1C(=O)c1cccc(O)c1C3=O)C2=O</smiles>

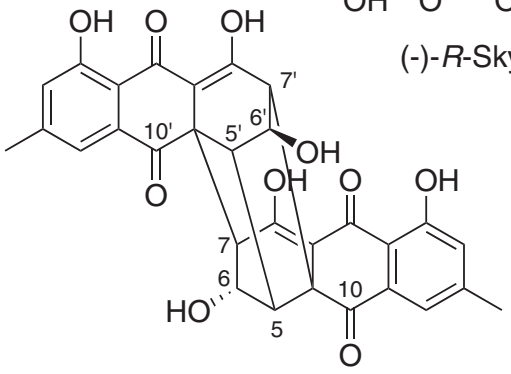

(+)-Rugulosin A (3)

Figure 1 Compounds isolated from Chrysoporthe sp. SNB-CN74.
Relative stereochemistry was determined upon examination of the coupling constants in the cyclohexane ring and the observation of the NOE correlations (Figure 3). H-3ax had three large coupling constants, indicating that $\mathrm{H}-4$ was axial. The methyl group at C-14 was therefore equatorial. The NOE correlations between $\mathrm{H}-15$ and $\mathrm{H}-1 \mathrm{ax}$, and between $\mathrm{H}-3 \mathrm{ax}$ and $\mathrm{H}-6$ indicated that these protons were on the same side of the molecule. The stereochemistry at C-7 is governed by the oxiran ring and the stereochemistry at C- 8 remained uncertain. However, the NOE correlations between H12a and H-8, and between H12a and H-6 may indicate that these three protons were on the same side of the molecule in the most stable conformer around the C-7-C-11 single bond. This assumption was confirmed by the NOE spectroscopy and the ROE spectroscopy experiments conducted in DMSO-d6 with the observation of a correlation between $\mathrm{H}-8$ and $\mathrm{H}-15$ indicating that these protons are indeed on the same side of the molecule (Supplementary Table S1 in the Supplementary Information).

Compound 2 was identified as (-)-R-skyrin based on NMR, HRMS and optical rotation. $22,23(-)-R$-Skyrin is less frequent than its enantiomer, although it has been already isolated in the past from fungal sources. ${ }^{24,25}$

Compound 3 was identified as (+)-rugulosin A. The spectral data were identical to those already described in the literature. ${ }^{26,27}$

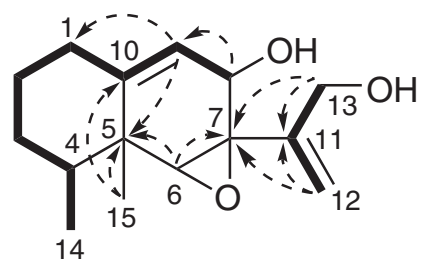

Figure 2 Proton to carbon HMBC (dashed arrows) and proton to proton COSY (bold) correlations in 1.

Table 1 NMR data for phomenol (1) in $\mathrm{CDCl}_{3}$

\begin{tabular}{|c|c|c|c|c|c|}
\hline Position & $\delta_{C}$, type & $\delta_{H}(J$ in $H z)$ & $\cos Y$ & $H M B C^{\text {a }}$ & NOESY \\
\hline 1 & 32.3, $\mathrm{CH}_{2}$ & $\begin{array}{l}\text { eq: } 2.12 \mathrm{~m} \\
\text { ax: } 2.20 \mathrm{~m}\end{array}$ & $\begin{array}{c}1 \mathrm{ax}, 2 \mathrm{eq}, 2 \mathrm{ax} \\
1 \mathrm{eq}, 2 \mathrm{eq}, 2 \mathrm{ax}, 8,9\end{array}$ & & $\begin{array}{l}1 \mathrm{ax}, 2 \mathrm{eq}, 9 \\
1 \mathrm{eq}, 15\end{array}$ \\
\hline 2 & $26.5, \mathrm{CH}_{2}$ & $\begin{array}{c}\text { ax: } 1.34 \text { br. qt }(J=13.4,3.8) \\
\text { eq: } 1.74 \mathrm{~m}\end{array}$ & $\begin{array}{c}1 \text { eq, 2eq, 3eq } \\
1 \text { eq, 1ax, 2ax, 3eq, 3ax }\end{array}$ & 10 & $\begin{array}{c}2 \mathrm{eq}, 3 \mathrm{eq} \\
1 \mathrm{eq}, 2 \mathrm{ax}, 3 \mathrm{eq}\end{array}$ \\
\hline 3 & $30.3, \mathrm{CH}_{2}$ & $\begin{array}{c}\text { ax: } 1.39 \text { br. qd }(J=13.2,3.1) \\
\text { eq: } 1.56 \mathrm{~m}\end{array}$ & $\begin{array}{c}\text { 2eq, 3eq, } 4 \\
\text { 2eq, 2ax, 3ax, } 4\end{array}$ & 2 & $\begin{array}{c}\text { 3eq, 14, } 15 \\
\text { 2eq, 2ax, 3ax, } 14\end{array}$ \\
\hline 4 & $36.7, \mathrm{CH}$ & $1.75 \mathrm{~m}$ & 3eq, 3ax, 14 & & 14 \\
\hline 5 & $38.3, \mathrm{C}$ & & & & \\
\hline 6 & $68.4, \mathrm{CH}$ & $3.19 \mathrm{~s}$ & & $5,7,10,11,15$ & $12 \mathrm{a}, 14,15$ \\
\hline 7 & $64.5, \mathrm{C}$ & & & & \\
\hline 8 & $67.0, \mathrm{CH}$ & 4.53 br. t $(J=2.9)$ & $1 \mathrm{ax}, 9$ & 9,10 & $12 \mathrm{a}$ \\
\hline 9 & $118.0, \mathrm{CH}$ & 5.21 br. $\mathrm{t}(J=2.4)$ & $1 \mathrm{ax}, 8$ & $1,5,7$ & $1 \mathrm{eq}, 8$ \\
\hline 10 & $142.2, \mathrm{C}$ & & & & \\
\hline 11 & 146.0, C & & & & \\
\hline 12 & $115.4, \mathrm{CH}_{2}$ & $\begin{array}{l}\text { a: } 5.29 \text { d }(J=1.2) \\
\text { b: } 5.35 \text { q }(J=1.2)\end{array}$ & $\begin{array}{c}12 b \\
12 a, 13 a, 13 b\end{array}$ & $\begin{array}{l}7,11,13 \\
7,11,13\end{array}$ & $\begin{array}{c}6,8,12 b \\
12 a, 13 a, 13 b\end{array}$ \\
\hline 13 & 64.0, $\mathrm{CH}_{2}$ & $\begin{array}{l}\text { a: } 4.19 \mathrm{dd}(J=12.9,1.2) \\
\text { b: } 4.32 \mathrm{dd}(J=12.9,1.2)\end{array}$ & $\begin{array}{l}12 b, 13 b \\
12 b, 13 a\end{array}$ & $\begin{array}{l}7,11,12 \\
7,11,12\end{array}$ & $\begin{array}{l}12 b, 13 b \\
12 b, 13 a\end{array}$ \\
\hline 14 & $15.9, \mathrm{CH}_{3}$ & $1.01 \mathrm{~d}(J=6.8)$ & 4 & $3,4,5$ & $3 e q, 4,6$ \\
\hline 15 & 16.3, $\mathrm{CH}_{3}$ & $1.03 \mathrm{~s}$ & & $5,6,10$ & $1 \mathrm{ax}, 3 \mathrm{ax}, 6$ \\
\hline
\end{tabular}

Abbreviations: ax, axial; eq, equivalent.

A HMBC correlations, optimized for $8 \mathrm{~Hz}$, are from proton(s) stated to the indicated carbon.
a 


\section{Biological activity}

All compounds isolated from Chrysoporthe sp. SNB-CN74 were tested on microbial human pathogens (Table 2). The cytotoxicities toward human non-cancer MRC5 cells were recorded to evaluate the antimicrobial selectivity. All compounds were inactive against fungi, but (-)-R-skyrin (2) and (+)-rugulosin A (3) were strongly antibacterial, with remarkable selectivity indexes. Interestingly, (-)-Rskyrin was more active than the positive control against the Gramnegative strain of E. coli, whereas (+)-rugulosin A was more efficient on the Gram-positive bacterium S. aureus.

\section{Reinduction of the antibacterial compounds synthesis}

After the discovery of its antibacterial potential and before the identification of the active metabolites, the fungus Chrysoporthe sp. SNB-CN74 was cultivated on a large scale to generate more crude material. The crude extract obtained from this large-scale cultivation was inactive. It was also colorless, whereas the active extract was dark orange. After isolating compounds $\mathbf{2}$ and $\mathbf{3}$ on the small scale, it was obvious that the two antibiotic metabolites were colored and were therefore absent in the inactive large-scale extract. This assumption was confirmed by the HPLC profiling, and (-)-R-skyrin and (+)-rugulosin A can thus be considered as activity markers of this specific strain that are visible to the naked eye. Chrysoporthe sp. SNB-CN74 was therefore an ideal strain to undertake metabolite re-expression studies. In one of the Petri dishes of the large-scale cultivation, a fungal contaminant was surrounded with an orange halo (Figure 4).

Although the outsider was a fungus, it was detected as a potential competitor and induced an antibiose-like reaction of Chrysoporthe sp.

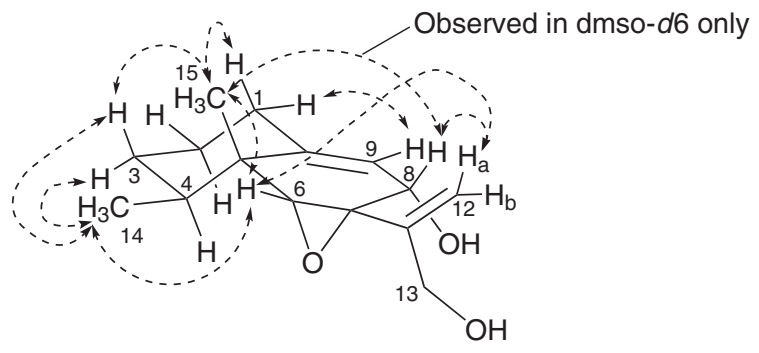

Figure 3 Key NOE correlations in $\mathbf{1}$.
SNB-CN74. ${ }^{28,29}$ There are many examples in the literature describing the discovery of fungal metabolites through epigenetic activation. ${ }^{30}$ Here the intruder acted as an epigenetic key that opened a silent biosynthetic pathway. It was therefore sought to mimic this process with a fanciful outsider. SNB-CN74 culture recovered a deep orange coloration on potato dextrose agar (PDA) supplemented with $5 \mathrm{gl}^{-1}$ yeast autolysate. The ethyl acetate extract from this culture recovered the antibacterial activity of this initial extract $\left(16 \mu \mathrm{g} \mathrm{ml}^{-1}\right)$. With a higher concentration of yeast autolysate $\left(10\right.$ and $\left.20 \mathrm{gl}^{-1}\right)$, the extracts were light orange and were less active $\left(64\right.$ and $256 \mu \mathrm{g} \mathrm{ml}^{-1}$, respectively). HPLC profiling confirmed that compounds 2 and 3 were present both in the initial active extract and in the orange extract generated from the culture with $5 \mathrm{gl}^{-1}$ yeast autolysate (Figures $5 \mathrm{a}$ and c), and were absent in the inactive culture (Figure 5b, the peak of rugulosine (2) corresponds to a very small relative proportion of this metabolite, which has a strong specific absorbance at $210 \mathrm{~nm}$; it was not detected with an evaporating light scattering detector).

In conclusion, this study of Chrysoporthe sp. SNB-CN74 has allowed us to isolate phomenol (1), as well as the two known antibacterial agents (-)-R-skyrin (2) and (+)-rugulosin A (3). These two metabolites have proven active on human pathogens, the first one being more efficient on Gram-negative E. coli and the second more active on Gram-positive $S$. aureus. The presence of these metabolites in the fungal extract was somewhat labile, and it was possible to reactivate antibiosis with yeast autolysate. The latter was presumably detected as

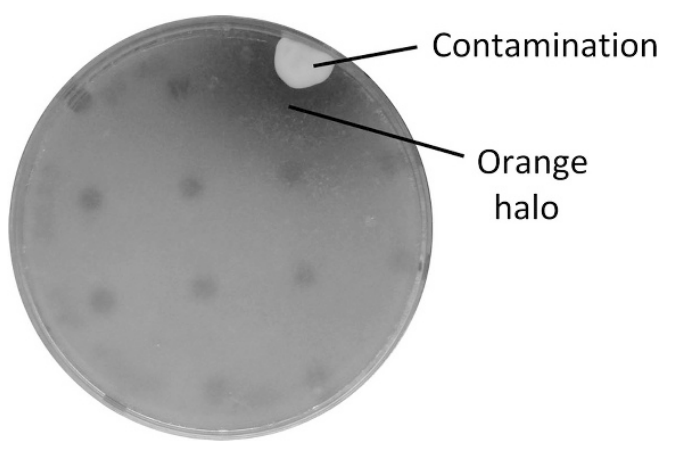

Figure $4 \mathrm{~A}$ fungal contaminant in Chrysoporthe sp. SNB-CN74 culture surrounded with an orange halo. A full color version of this figure is available at The Journal of Antibiotics journal online.

Table 2 MIC and SI of the isolated compounds

\begin{tabular}{|c|c|c|c|c|c|c|c|}
\hline \multirow{2}{*}{ Strain } & \multicolumn{4}{|c|}{$M I C\left(\mu g m l^{-1}\right)$} & \multicolumn{3}{|c|}{$S /^{a}$} \\
\hline & 1 & 2 & 3 & Pos.ctrl. ${ }^{\mathrm{b}}$ & 1 & 2 & 3 \\
\hline S. aureus (ATCC 29213) & $>256$ & 16 & $\leq 0.5$ & 0.5 & - & 2.3 & $\geqslant 102.4$ \\
\hline E. coli (ATCC 25922) & $>256$ & 4 & 16 & 8 & - & 9.3 & $>3.2$ \\
\hline C. albicans (ATCC 10231) & $>256$ & $>256$ & $>256$ & 4 & - & - & - \\
\hline A. fumigatus (SNB-AF1) & $>256$ & $>256$ & $>256$ & 0.5 & - & - & - \\
\hline \multirow[t]{2}{*}{ T. rubrum (SNB-TR1) } & 128 & $>256$ & 128 & 0.03 & $>0.4$ & - & $>0.4$ \\
\hline & IC50 $(\mu \mathrm{M})$ & & & & & & \\
\hline MRC5 & $>204.5$ & 69.3 & $>94.4$ & 0.0005 & - & - & - \\
\hline
\end{tabular}

Abbreviations: Pos. ctrl., positive control; SI, selectivity indexes.

aSI $=I C_{50} / \mathrm{MIC}$ based on $\mathrm{IC}_{50}$ measured on MRC5 cell line.

bositive controls: S. aureus: Oxacillin; E. coli: gentamicin; C. albicans: fluconazole; filamentous fungi: Itraconazole; MRC5: docetaxel. 


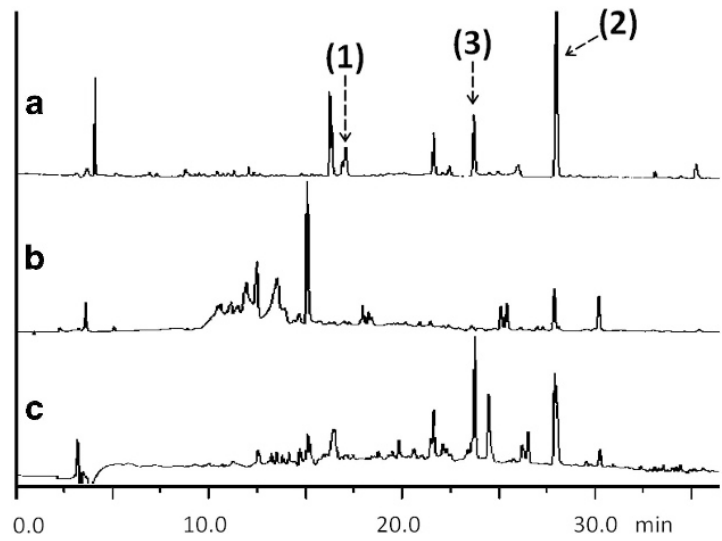

Figure 5 UV traces $(210 \mathrm{~nm})$ of (a) initial active extract; (b) inactive extract from large-scale cultivation; (c) extract from culture with $5 \mathrm{gl}^{-1}$ yeast autolysate.

an environmental competitor by Chrysoporthe sp. SNB-CN74 and acted as an epigenetic modifier. This approach allowed the expression of a silent metabolic pathway and could open new opportunities in the discovery of original bioactive metabolites from fungi.

\section{EXPERIMENTAL PROCEDURE}

\section{General experimental procedures}

Optical rotation was measured using an Anton Paar MCP 300 polarimeter in a 100-mm long 350- $\mu$ l cell. NMR spectra were recorded on a Bruker $500 \mathrm{MHz}$ spectrometer (Bruker-Biospin, Billerica, MA, USA). Chemical shifts $(\delta)$ are reported as p.p.m. based on the TMS signal. High-resolution ESI time-of-flight mass MS measurements were performed using a Waters Acquity UPLC system with column bypass coupled to a Waters Micromass LCT Premier time-offlight mass spectrometer equipped with an ESI (Waters, Milford, MA, USA). Analytical and preparative HPLCs were conducted with a Gilson system equipped with a 322 pumping device, a GX-271 fraction collector, a 171 diode array detector, and a prepELSII detector electrospray nebulizer. The columns used for these experiments included a Phenomenex Luna C18, $5 \mu \mathrm{m}$, $4.6 \times 250 \mathrm{~mm}$ for analytical HPLC and a Sunfire (Waters) C18, $5 \mu \mathrm{m}$, $10 \times 150 \mathrm{~mm}$ for preparative HPLC. The flow rate was set to 1 or $4 \mathrm{ml} \mathrm{min}^{-1}$, respectively, using a linear gradient of $\mathrm{H}_{2} \mathrm{O}$ mixed with an increasing proportion of $\mathrm{CH}_{3} \mathrm{CN}$. Both solvents were modified with $0.1 \%$ formic acid. All solvents were HPLC grade. PDA and yeast extract were purchased from Fluka Analytical (Sigma-Aldrich, St Louis, MO, USA).

\section{Fungal material}

The strain was isolated from a Nasutitermes corniger termite aerial nest sampled in Rémire-Montjoly, French Guiana in July 2011. N. coniger belong to the Termitidae family. Nasutitermes is the most frequent genus in French Guiana, representing more than half of the genera inventoried in the territory. ${ }^{31}$ Nasutitermes species are easily identified by the specific pear-shaped head of soldier individuals. The termites were collected from a dark brown arboreal nest built $1.5 \mathrm{~m}$ above ground. The nest was $\sim 1-\mathrm{m}$ high and $20-\mathrm{cm}$ wide and was located in a seashore area (Supplementary Figure S11 in Supplementary Information). A piece of the nest matter was placed in suspension in sterile water, and this solution was spread on PDA medium. After 1 week of incubation at $25^{\circ} \mathrm{C}$, the first fungal hyphae were removed and transferred to another Petri dish. The colony was maintained in triplicate at $-80^{\circ} \mathrm{C}$ in glycerol- $\mathrm{H}_{2} \mathrm{O}$ (50/50). A sample submitted for amplification and nuclear ribosomal internal transcribed spacer region ITS4 sequencing allowed for strain identification by NCBI sequence comparison. The sequence has been registered in the NCBI GenBank database (http://www.ncbi.nlm.nih.gov) under registry number KJ023737. Molecular analysis was performed externally by BACTUP, France.

\section{Extraction and isolation}

The Chrysoporthe sp. SNB-CN74 strain was cultivated on PDA at $26^{\circ} \mathrm{C}$ for 15 days, initially on a small scale $(6,10-\mathrm{cm}$ diameter Petri dishes) for the biological screening. The fungus and the culture medium were then transferred into an Erlenmeyer flask and macerated with EtOAc for $24 \mathrm{~h}$. The organic solvent was collected by filtration, washed with $\mathrm{H}_{2} \mathrm{O}$ in a separating funnel and evaporated, yielding $75.7 \mathrm{mg}$ of extract. The crude extract was purified by preparative HPLC with $\mathrm{H}_{2} \mathrm{O} / \mathrm{ACN}$ ( $95 / 5$ to $0 / 100$ in $30 \mathrm{~min}, 0 / 100$ during $10 \mathrm{~min}$; flow rate $\left.4 \mathrm{ml} \mathrm{min}^{-1}\right)$, which led to the isolation of phomenol (1, $\left.2.1 \mathrm{mg}, t_{\mathrm{R}}=14.50 \mathrm{~min}\right),(-)-R$-skyrin $\left(2,1.9 \mathrm{mg}, t_{\mathrm{R}}=24.83 \mathrm{~min}\right)$ and $(+)$-rugulosin A (3, $\left.1.4 \mathrm{mg}, t_{\mathrm{R}}=20.74 \mathrm{~min}\right)$.

Phomenol (1): colorless oil; $[\alpha]^{25} \mathrm{D}+23.3(c 0.21, \mathrm{MeOH}) ;{ }^{1} \mathrm{H}-\mathrm{NMR}(500$ $\left.\mathrm{MHz}, \mathrm{CDCl}_{3}\right)$ see Table $1 ;{ }^{13} \mathrm{C}$-NMR $\left(125 \mathrm{MHz}, \mathrm{CDCl}_{3}\right)$ see Table 1 ; HRESIMS $\mathrm{m} / \mathrm{z} 251.1650[\mathrm{M}+\mathrm{H}]^{+}$(calcd for $\mathrm{C}_{15} \mathrm{H}_{23} \mathrm{O}_{3}, 251.1647$ ).

(-)-R-Skyrin (2): orange solid; $[\alpha]^{25} \mathrm{D}-105.6$ (c 0.16, dioxan); ${ }^{1} \mathrm{H}$ NMR $\left(500 \mathrm{MHz}, \mathrm{DMSO}-d_{6}\right) \delta 12.78\left(2 \mathrm{H}, \mathrm{s}, 8-\mathrm{OH} / 8^{\prime}-\mathrm{OH}\right), 12.02\left(2 \mathrm{H}, \mathrm{s}, 1-\mathrm{OH} / 1^{\prime}-\right.$ $\mathrm{OH}), 11.15\left(2 \mathrm{H}, \mathrm{s}, 6-\mathrm{OH} / 6^{\prime}-\mathrm{OH}\right), 7.28\left(2 \mathrm{H}, \mathrm{s}, \mathrm{H}-4 / \mathrm{H}-4^{\prime}\right), 7.15(2 \mathrm{H}, \mathrm{s}, \mathrm{H}-2 /$ $\left.\mathrm{H}-2^{\prime}\right), 6.73\left(2 \mathrm{H}, \mathrm{s}, \mathrm{H}-7 / \mathrm{H}-7^{\prime}\right), 2.33\left(6 \mathrm{H}, \mathrm{s}, 3-\mathrm{CH}_{3} / 3^{\prime}-\mathrm{CH}_{3}\right) ;{ }^{13} \mathrm{C}$ NMR $(125$ $\left.\mathrm{MHz}, \mathrm{DMSO}-d_{6}\right) \delta 189.7$ (C-9/C-9), 182.0 (C-10/C-10'), 164.3 (C-6/C-6'), 164.3 (C-8/C-8'), 161.2 (C-1/C-1'), 148.2 (C-3/C-3'), 133.2 (C-4a/C-4a'), 131.2 (C-10a/C-10a'), 123.6 (C-2/C-2'), 123.4 (C-5/C-5'), 120.2 (C-4/C-4'), 113.0 (C-9a/C-9a'), 109.1 (C-8a/C-8a'), 107.0 (C-7/C-7'), $21.2\left(\mathrm{C}-3-\mathrm{CH}_{3} / \mathrm{C}-3^{\prime}-\mathrm{CH}_{3}\right)$; HRESIMS $m / z 539.0966[\mathrm{M}+\mathrm{H}]^{+}$(calcd for $\mathrm{C}_{30} \mathrm{H}_{19} \mathrm{O}_{10}, 539.0978$ ).

(+)-Rugulosin A (3): yellow-orange solid; $[\alpha]^{25} \mathrm{D}+206.6$ (c 0.18, dioxan); ${ }^{1} \mathrm{H}$ NMR $\left(500 \mathrm{MHz}, \mathrm{DMSO}-d_{6}\right) \delta 14.71\left(2 \mathrm{H}, \mathrm{s}, 8-\mathrm{OH} / 8^{\prime}-\mathrm{OH}\right), 11.40(2 \mathrm{H}, \mathrm{s}, 1-$ $\left.\mathrm{OH} / 1^{\prime}-\mathrm{OH}\right), 7.44\left(2 \mathrm{H}, \mathrm{s}, \mathrm{H}-4 / \mathrm{H}-4^{\prime}\right), 7.18\left(2 \mathrm{H}, \mathrm{s}, \mathrm{H}-2 / \mathrm{H}-2^{\prime}\right), 5.42(2 \mathrm{H}, \mathrm{s}, 6-\mathrm{OH} /$ 6'- $\mathrm{OH}), 4.38\left(2 \mathrm{H}, \mathrm{t}, J=5.4 \mathrm{~Hz}, \mathrm{H}-6 / \mathrm{H}-6^{\prime}\right), 3.36\left(2 \mathrm{H}, \mathrm{brs}, \mathrm{H}-5 / \mathrm{H}-5^{\prime}\right), 2.76(2 \mathrm{H}$, d, $\left.J=5.4 \mathrm{~Hz}, \mathrm{H}-7 / \mathrm{H}-7^{\prime}\right), 2.43\left(6 \mathrm{H}, \mathrm{s}, 3-\mathrm{CH}_{3} / 3^{\prime}-\mathrm{CH}_{3}\right) ;{ }^{13} \mathrm{C} \mathrm{NMR}(125 \mathrm{MHz}$, DMSO- $\left.d_{6}\right) \delta 194.6$ (C-10/C-10'), 186.0 (C-9/C-9), 159.4 (C-1/C-1'), 147.4 (C-3/C-3'), 131.9 (C-4a/C-4a'), 123.9 (C-2/C-2'), 120.5 (C-4/C-4'), 114.0 (C-9a/C-9a'), 105.8 (C-8a/C-8a'), 68.5 (C-6/C-6'), 58.5 (C-7/C-7'), 55.6 (C-10a/C-10a'), 47.7 (C-5/C-5'), $21.4\left(\mathrm{C}-3-\mathrm{CH}_{3} / \mathrm{C}-3^{\prime}-\mathrm{CH}_{3}\right)$, n.d. (C-8/C-8'); HRESIMS $m / z 543.1306[\mathrm{M}+\mathrm{H}]^{+}\left(\right.$calcd for $\left.\mathrm{C}_{30} \mathrm{H}_{23} \mathrm{O}_{10}, 543.1291\right)$.

\section{Cultivation with yeast autolysate}

Chrysoporthe sp. SNB-CN74 was cultivated on PDA supplemented with 5, 10 or $20 \mathrm{gl}^{-1}$ Saccharomyces yeast autolysate (Sigma-Aldrich). After 15 days at $26^{\circ} \mathrm{C}$, the whole fungus+PDA was macerated with ethyl acetate as described above.

\section{Antibacterial assays}

The species of human pathogenic microorganisms used in this study were the Gram-negative bacterium E. coli (ATCC 25922), the Gram-positive bacterium S. aureus (ATCC 29213), the yeast Candida albicans ATCC 10231 and two clinical isolates of filamentous fungi Aspergillus fumigatus SNB-AF1 and Trichophyton rubrum SNB-TR1. The extracts and pure compounds were tested according to the reference protocol of the European Committee on Antimicrobial Susceptibility Testing. ${ }^{32,33}$ The MIC was read after $18 \mathrm{~h}$ for $C$. albicans, after 5 days for filamentous fungi and after $24 \mathrm{~h}$ for the bacteria. All of the assays were conducted in duplicate. The extract obtained from the culture medium (blank) was tested in all assays and did not present significant activity.

\section{Cytotoxic assays}

The cytotoxicity assays were conducted with normal human lung fibroblast cells MRC5 (ATCC CCL-171) according to the procedure described by Tempête et al. ${ }^{34}$

\section{ACKNOWLEDGEMENTS}

This work has benefited from an 'Investissement d'Avenir' grant managed by the Agence Nationale de la Recherche (CEBA, ref ANR-10-LABX-0025). We are grateful to Professor Philippe Loiseau for providing wild strains of pathogenic fungi and to Professor Reginaldo Constantino for the identification of the host termite. 
1 Purvis, A. \& Hector, A. Getting the measure of biodiversity. Nature 405 212-219 (2000).

2 Ramadhar, T. R., Beemelmanns, C., Currie, C. R. \& Clardy, J. Bacterial symbionts in agricultural systems provide a strategic source for antibiotic discovery. J. Antibiot. 67, 53-58 (2014).

3 Berenbaum, M. R. \& Eisner, T. Bugs' bugs. Science 322, 52-53 (2008).

4 Stow, A. \& Beattie, A. Chemical and genetic defenses against disease in insect societies. Brain Behav. Immun. 22, 1009-1013 (2008).

5 Sadd, B. M. \& Schmid-Hempel, P. Insect immunity shows specificity in protection upon secondary pathogen exposure. Curr. Biol. 16, 1206-1210 (2006).

6 Currie, C. R., Scott, J. A., Summerbell, R. C. \& Malloch, D. Fungus-growing ants use antibiotic-producing bacteria to control garden parasites. Nature 398, 701-704 (1999).

7 Currie, C. R., Poulsen, M., Mendenhall, J., Boomsma, J. J. \& Billen, J. Coevolved crypts and exocrine glands support mutualistic bacteria in fungus-growing ants. Science $\mathbf{3 1 1}$ 81-83 (2006).

8 Oh, D.-C., Poulsen, M., Currie, C. R. \& Clardy, J. Dentigerumycin: a bacterial mediator of an ant-fungus symbiosis. Nat. Chem. Biol. 5, 391-393 (2009).

9 Kroiss, J. et al. Symbiotic Streptomycetes provide antibiotic combination prophylaxis for wasp offspring. Nat. Chem. Biol. 6, 261-263 (2010).

10 Kellner, R. L. L. Molecular identification of an endosymbiotic bacterium associated with pederin biosynthesis in Paederus sabaeus (Coleoptera: Staphylinidae). Insect Biochem. Mol. Biol. 32, 389-395 (2002).

11 Scott, J. J. et al. Bacterial protection of beetle-fungus mutualism. Science $\mathbf{3 2 2}$, 63 (2008).

12 Oh, D.-C., Scott, J. J., Currie, C. R. \& Clardy, J. Mycangimycin, a polyene peroxide from a mutualist Streptomyces sp. Org. Lett. 11, 633-636 (2009).

13 Banks, H. J. \& Cameron, D. W. Polyhydroxyanthraquinones from the insect Eriococcus coriaceus. J. Chem. Soc. D. Chem. Commun. 22, 1577-1578 (1970).

14 Cantley, A. M. \& Clardy, J. Animals in a bacterial world: opportunities for chemical ecology. Nat. Prod. Rep. doi:10.1039/C4NP00141A. (in the press).

15 Matsui, T., Tanaka, J., Namihira, T. \& Shinzato, N. Antibiotics production by an actinomycete isolated from the termite gut. J. Basic Microbiol. 52, 731-735 (2012).

16 Um, S., Fraimout, A., Sapountzis, P., Oh, D.-C. \& Poulsen, M. The fungus-growing termite Macrotermes natalensis harbors bacillaene-producing Bacillus sp. that inhibit potentially antagonistic fungi. Sci. Rep. 3, 3250 (2013).

17 Nirma, C., Eparvier, V. \& Stien, D. Antifungal agents from Pseudallescheria boydi SNB-CN73 isolated from a Nasutitermes sp. termite. J. Nat. Prod. 76, 988-991 (2013).

18 Nirma, C., Eparvier, V. \& Stien, D. Antibacterial Ilicicolinic Acids C and D and Ilicicolinal from Neonectria discophora SNB-CN63 Isolated from a Termite Nest. J. Nat. Prod. 78, 159-162 (2015).
19 Capasso, R., lacobellis, N. S., Bottalico, A. \& Randazzo, G. Structure-toxicity relationships of the eremophilane phomenone and PR-toxin. Phytochemistry 23 2781-2784 (1984).

20 Hatakeyama, T., Koseki, T., Murayama, T. \& Shiono, Y. Eremophilane sesquiterpenes from the endophyte Microdiplodia sp. KS 75-1 and revision of the stereochemistries of phomadecalins C and D. Phytochem. Lett. 3, 148-151 (2010).

21 Che, Y., Gloer, J. B. \& Wicklow, D. T. Phomadecalins A-D and Phomapentenone A: New Bioactive Metabolites from Phoma sp. NRRL 25697, a Fungal Colonist of Hypoxylon Stromata. J. Nat. Prod. 65, 399-402 (2002).

22 Thomson, R. H. Naturally Occurring Quinones III 706 (Chapman \& Hall, London, 1987).

23 Gill, M., Gimenez, A. \& McKenzie, R. W. Pigments of Fungi, Part 8. Bianthraquinones from Dermocybe austroveneta. J. Nat. Prod. 51, 1251-1256 (1988).

24 Natori, S., Sato, F. \& Udagawa, S. Anthraquinone metabolites of Talaromyces avellaneus (Thom et Turreson) and Preussia multispora (Saito et Minoura) Cain. Chem Pharm. Bull. 13, 385-386 (1965).

25 Koyama, K., Aida, S. \& Natori, S. Supplemental Observations on Atropisomerism of Fungal Bis(naphtho- $\gamma$-pyrones)s. Chem. Pharm. Bull. 38, 2259-2261 (1990).

26 Takeda, N. et al. Studies on fungal metabolites-XXXI. Tetrahedron 29, 3703-3719 (1973).

27 Yamazaki, H., Koyama, N., Omura, S. \& Tomoda, H. New rugulosins, anti-MRSA antibiotics, produced by Penicillium radicum FKI-3765-2. Org. Lett. 12 1572-1575 (2010).

28 Combès, A. et al. Chemical communication between the endophytic fungus Paraconiothyrium variabile and the phytopathogen Fusarium oxysporum. PLoS One 7 e47313 (2012)

29 Bertrand, S. et al. De Novo production of metabolites by fungal co-culture of Trichophyton rubrum and Bionectria ochroleuca. J. Nat. Prod. 76, 1157-1165 (2013).

30 Cichewicz, R. H. Epigenome manipulation as a pathway to new natural product scaffolds and their congeners. Nat. Prod. Rep. 27, 11-22 (2010).

31 Lefeuve, P. A propos des Termites de Guyane française. Bois des Forêts Trop 224 59-64 (1990).

32 EUCAST. EUCAST definitive document EDef 7.1: method for the determination of broth dilution MICs of antifungal agents for fermentative yeasts. Clin. Microbiol. Infect. 14, 398-405 (2008).

33 EUCAST. EUCAST DISCUSSION DOCUMENT E.Dis 5.1 Determination of minimum inhibitory concentrations (MICs) of antibacterial agents by broth dilution. Clin. Microbiol. Infect. 9, 1-7 (2003).

34 Tempête, C., Werner, G. \& Favre, F. In vitro cytostatic activity of 9-demethoxyporothramycin B. Eur. J. Med. Chem. 30, 647-650 (1995).

Supplementary Information accompanies the paper on The Journal of Antibiotics website (http://www.nature.com/ja) 